Since that time, however, this Drosophila has provided most important data in subjects which are considered to be the province of the taxonomist, ecologist and morphologist.

Its intrinsic value as an organism about which we know more of its heritable characters than of any other living thing gives Drosophila a position which cannot be ignored when discussing the evolutionary problems and behaviour of organisms in the wild. The 'drosophilists' have realized the importance of wild population studies and are providing and accumulating many data in the United States.

It is fortunate that two monographs have just been issued ${ }^{1,2}$ under the names of the late Dr. C. Bridges and Dr. K. S. Brehme, and Prof. J. T. Patterson, respectively. The first is a valuable and possibly classical work on the known characters of Drosophila. After listing the symbolization used in Drosophila literature in a form comprehensible to an ordinary geneticist, the inherited characters are described, together with the positions of the related genes on the chromosomes, their origins and authorities. These data, included in two hundred pages, are followed by chromosome maps of the genes which leave all other published maps far behind. A fitting conclusion to the publication is the inclusion of the salivary chromosome maps originally published in the Journal of Heredity. The conception of this work was designed by Dr. M. Demerec, director of the Carnegie Institution, and with the co-operation of many geneticists the compilation by Dr. Brehme is a fitting memorial to Dr. Bridges. This publication gives the biologist an accurate description of the genetic characters of Drosophila melanogaster.

The publication by Patterson and his co-workers carries, as it were, the attack into the enemy's camp. Here the species of Drosophila which have been found in the south-west of the United States and Mexico are described with the meticulous care of the systematist, and each is illustrated with coloured plates. Twenty-four new forms are described for the first time, while numerous data from collecting work provides an insight into geographical distribution and reasons for the fluctuations in numbers in wild populations. J. T. Patterson and R. P. Wagner consider the distribution of the species of Drosophila throughout the United States and give data on the reactions of different species to ecological factors. L. J. Wharton describes the metaphase complements and the salivary gland chromosomes of eighty Drosophila species.

As a result of these investigations on an animal the genetical constitution of which is better known than that of any other, it is possible to raise doubts and to call for reconsideration of important current and established theories, some of which are keystones in branches of biology. For example, it is clearly seen that homology between parts of chromosomes in related species cannot be assumed without hybridization experiments and linkage studies. Similar characters in different species may depend on different genic origins. This being so, to what extent can homology of characters in different organisms be utilized as has been done in the past by morphologists as a criterion in evolution? Does the different origin and development of a character affect the validity of the evidence derived from analysing such characters in different phyla ?

Again, there is strong evidence in Drosophila that phylogenetic relationships based on metaphase chromosome idiograms may be invalid unless sup- ported by salivary gland chromosome analysis or cross-over configurations and other genetical criteria.

On the problem of speciation, the distribution of the species of Drosophila in the United States is interesting. A very few species are widespread while a larger number of species, many of which are local, are found in areas where there is great environmental diversity.

The reviewer is impressed by the painstaking work, the absence of contentious or other theories and the manner in which the solid results become related into a coherent whole. The evidence touches on many fields of biology and it is salutary, and we believe necessary, to consider it in relation to current theories in different branches of botany and zoology.

$$
\text { F. W. SANSOMA. }
$$

1 Bridges, C. B., and Brehme, K. S., "The Mutants of Drosophila melanogaster", Carnegie Institution of Washington Pub. 552 (1944). "Patterson, J. T., "Studies in the Genetics of Drosophila III", University of Texas Pub. 4313 (1944), 2.50 dollars.

\section{SUMERIAN MYTHOLOGY*}

$\mathrm{T}$ O-DAY everyone in the least interested in archæology has heard of the Sumerian culture of Mesopotamia and the cuneiform system of writing that was developed there. Not everyone realizes that only so recently as 1850 was the existence of this all-important non-Indo-European and nonSemitic people so much as suspected. Nowadays, of course, the Sumerians take pride of place as the dominant cultural element in Mesopotamia from the fourth to nearly the beginning of the second millennium B.c., and the influence of their culture is known to have spread far and wide and to have lasted long after the folk themselves had been swamped by their Semitic neighbours. Why are there to-day sixty seconds in a minute, sixty minutes in an hour, and $6 \times 60$ degrees in a circle ? Because the Sumerians used a unit of sixty. Their unit of weight, the mina, seems to have been just about equal to the Imperial pound.

The Sumerians used tablets of clay to write on, and many thousands of these have turned up in the course of excavations. More particularly is this true of the American excavations at Nippur, which were carried on at intervals between 1889 and 1900 . But the writing is difficult to interpret and much of the material is broken; and in consequence a great deal still remains to be deciphered. Most of the quarter of a million or so tablets that have been unearthed are concerned with matters of business, but a small proportion, dating mostly to about 2000 B.c., can be classed as 'literary' tablets, and these are inscribed with Sumerian epics, myths, hymns, lamentations, proverbs and words of wisdom. There are also a number inscribed with mathematical texts and incantations Mr. S. N. Kramer is concerned to publish much of this hitherto undeciphered material in a number of volumes, of which this one on Sumerian mythology is the first. He has had the opportunity of working for nearly two years at the Nippur collections now in Turkey, as well as at those from the same site now housed in the United States. This first volume is extremely well put together and illustrated. It does not assume a greater knowledge of Mesopotamian

* Memoirs of the American Philosophical Society. Vol. 21 : Sumerian Mythology, a Study of Spiritual and Literary Achievement in the Third Millenium B.o. Pp. xiv +125+21 plates. By S. N. Kramer. 
archrology than can be obtained from any one of the well-known manuals.

After an explanatory preface and an introduction there is a chapter on the scope and significance of Sumerian mythology. This is followed by an account of the myths of origins, of Kur and the slaying of the dragon, of the deluge-antedating, of course, the well-known Neo-Babylonian epic-of the marriage of the god Martu, and of the preference of Inanna, sister of the sun-god Utu, for the farmer-god Enkimdu over the shepherd-god Dumuzi: a pretty story which ends with the seeming victory of Dumuzi over Enkimdu.

These Sumerian 'literary' tablets are some centuries older than the Neo-Babylonian epics, and borrowing by these can be detected. They are also about six hundred years older than the somewhat similar material which is turning up at Ras Shamra in northern Syria. Contact in Mesopotamia between the intrusive, matter-of-fact Sumerian folk of unknown racial affinity and their Semitic neighbours seems to have resulted in the development of epics, myths and proverbs which have proved a veritable mine into which later cultures have delved when they in turn set themselves to answer such problems as the origin of the world and man. It is to be hoped the subsequent volumes will appear without undue delay.

M. C. BurkitT.

\section{FORTHCOMING EVENTS}

\section{Tuesday, September 5}

WOMEN'S ENGINEERING SOCIETY (MANOHESTER BRANCH) (at the Engineers' Club, Albert Square, Manchester), at 6.30 p.m.-Mr. E. 'T. Norris: "The Moving Coil Voltage Regulator".

\section{Friday, September 8}

Royal Astronomical Socintr (at Burlington House, Piccadilly, London, W.1), at 4.30 p.m.--Sir Harold Spencer Jones, F.R.S., and Mr. R. T. Cullen: "The Division Errors of the Reversible Transit Circle of the Royal Observatory, Greenwich"; Mr. C. S. Beals : "Some Results of a Spectrophotometric Study of the Wolf Rayet Binary HD 193576"; Mr. D. L. Edwards: "Periodic Changes in $\gamma$ Cassiopeiae during the past 100 Years".

\section{APPOINTMENTS VACANT}

ApPLICATIONS are invited for the following appointments on or before the dates mentioned :

UNIVERSTTY READERSHIP IN PHYSICS tenable at King's CollegeThe Academic Registrar, University of London, South Kensington, London, S.W.7 (September 6)

HEAD OF THE DEPARTMENT OF Production ENGINERRING-The Principal, Leicester College of Technology and Commerce, Leicester (September 9).

IFCTURER IN CHEMISTRY-The Registrar, Technical College, Sunderland (September 9)

CHIEF FNaINFer by large firm of Locomotive Manufacturers-The Ministry of Labour and National Service, Room 432, Alexandra House, Kingsway, London, W.C.2 (quoting Reference No. C.2243.XA) House, Kingsway,

SPEECH THERAPIST-The Director of Education, Education Offices, 15 John Street, Sunderland (September 15).

15 John Street, Sunderland (September 15). of STUDIEs of the Correspondence Tuition Scheme of the Association OF STUDIEs of the Correspondence Tuition Scheme of the Association 102 St. George's Square, London, S.W.1 (endorsed 'Technical Editor') (September 15)

UNIVERSITY READERSHIP IN CHEMISTRY tenable at the Royal Cancer Hospital (Free)-The Academic Registrar, University of London, South Kensington, London, S.W.7 (September 18).

RESPONSIBLE LECTURER IN PHYSIOLOGY -The Principal, Chelsea Polytechnic, Manresa Road, London, S.W.3 (September 20). CHAIR of MrNING-The Acting Registrar, The University, Leeds 2
(September 30).

DIRECTOR OF RESEARCH, Forest Products Research Laboratory, Princes Risborough-The Secretary, Department of Scientific and Industrial Research, Teddington, Middx. (October 9).

LEOTURER IN PHILOSOPHY-The Very Rev. the Dean, Christ Church, Oxford (October 15).

DIREOTOR OF THE DEPARTMENT OF SOCIAL STUDIES, University of Sydney-The Secretary, Universities Bureau of the British Empire, clo University College, Gower Street, London, W.C.I (Sydney, December 1).
SECOND VETERINARY OFFICER at the Imperial Bureau of Animal Health, Weybridge-The Secretary, Imperial Agricultural Bureaux, 2 Queen Anne's Gate Buildings, London, S.W.1.

ASSISTANT MASTER (temporary) qualified to teach ENGINERRING SUBJECTS and MATHEMalios up to Ordinary National Certiflcate standard-The Principal, Technical Institute, Beckenham Road, Beckenham, Kent.

BOTANIST AND ORGANIC CHEMIST to the Nyasaland Research and Development Co., Ltd.-Dr. M. Nierenstein, 2 Rrlestone Grove, Bristol 9.

\section{REPORTS and other PUBLICATIONS}

\author{
(not included in the monthly Books Supplement)
}

\section{Great Britain and Ireland}

Pitt Rivers Museum: University of Oxford. Occasional Papers on Technology, 1: The Manufacture of a Flint Arrow-head by Quartz ite Hammer-stone. By Sir Francis H. S. Knowles. Pp. 38 (6 plates) 58 . Report of the Curator of the Pitt Rivers Museum (Department of Ethnology) for the Year ending 31 July 1943. Pp. 6. (Oxford: Pitt Rivers Museum.)

Tory Reform Committee. Bulletin No. 5: What Shall We Use for Money ? Pp. 16. (London: Tory Reform Committee.) [8 A Scientific Policy for British Agriculture (particularly in relation to Nutrition). Pp. 16. (London: Parliamentary and Scientific Ccmmittee.) 9d. 1108 Ministry of Fuel and Power: Committee on the Efficient Use of Fuel. Fuel Efficiency Bulletin No. 32: Fuel Economy at Collieries
with Ministry of Fuel and Power.) Institution of Gas Engineers. Communication No. 269: The Gas Industry ; some factors affecting Future Development. Pp. 56. (London : Institution of Gas Engineers.)
Royal College of Physicians of Edinburgh. Annual Report by the Curator of the Laboratory for the Year 1943. Pp. 12. (Edinburgh Royal College of Physicians of Edinburgh.) [218 The AScW and other Bodies. Pp. 8. (London: Association of British Rubber Producers' Research Association. Publication No. 49: Rubber, Polyisoprenes and Allied Compounds, Part 7: Action of Nitric Oxide Thereon. By G. F. Bloomfield and (in part) G. A. Jeffrey. Pp. 6. (London: British Rubber Producers' Research
Association.)
[218

Other Countries

Smithsonian Institution: United States National Museum. Bulletin 185: Checklist of the Coleopterous Insects of Mexico, Central America the West Indies and South America. Part 1. Compiled by Richard E. Blackwelder. Pp. xii + 188. (Washington, D.C.: Government Printing Office.) 35 cents. Department of Transport, Air Services Branch : Meteorological Division. Meteorolonsyt.)
[257 U.S. Department of Agriculture. Technical Bulletin No. 866: Nature and Extent of Mormon Cricket Damage to Crop and Range Plants. By Ralph B. Swain. Pp. 44. (Washington, D.C.: Govern-
ment Printing Office.) Annals of the Carnegie Museum. Vol. 30; Art. 5: A New Terrestrial Vulture from the Upper Eocene Deposits of Wyoming. By Alexander Wetmore. Pp. 57-70. Vol. 30, Art. 6: Another New Boa of the Genus Epicrates from the Bahamas. By M. Graham Netting and Coleman J. Goin. Pp. 71-76. (Pittsburgh, Pa.: Carnegie Museum.) [267 Smithsonian Institution: Bureau of American Ethnology. Bulletin 138: Stone Monuments of Southern Mexico. By Mat thew W. Stirling. Pp. vii $+84+62$ plates. 35 cents. Bulletin 141 : Ceramic Stratigraphy at Cerro de las Mesas, Veracruz, Mexico. By Philip Drucker. Pp.
viii $+95+58$ plates. 50 cents. (Washington, D.C.: Government Transactions of the American Philosophical Society. New Series, Vol. 33, Part 3: Infectious Anemias due to Bartonelia and related Red Cell Parasites. By David Weinman. Pp. 241-350. (Philadelphia: American Philosophical Society.) 1.25 dollars. Annual Report for the Uganda Protectorate: Forest Department. Annual Report for the
Year ending 31st December 194.3. Pp. 8. (Entebbe: Government Year ending 31st December 1943. Pp. 8. (Entebbe: Goverument
[317 Printer.) 18. Vol. 25, No. 2: Relations of the Temperate Floras of North and South America. By Doughton Houghton Campbell. Pp. 139-146. Vol. 25, No. 3: Pugillus astragalorum Alter. By R. C. Barneby. Pp. 147-170+plate 17. Vol. 25, No. 4 : Sublittoral Marine Algae of the Monterey Peninsula. By Prof. Gilbert M. Smith. Pp. 171-176. Vol. 25,
No. 5: The Gander Oak, a New Hybrid Oak from San Diego County, No. 5 : The Gander Oak, a New Hybrid Oak from San Diego County,
California. By Carl B. Wolf. Pp. 177-188 +plates 18-19. Vol. 25, California. By Carl B. Wolf. Pp. 177-188 tplates 18-19. Vol. 20, No. 6: The Genus Drymaria in, and adjacent to, the Sonoran Desert. By Prof. Ira I. Wiggins. Pp. 189-214 + plates 20-22. Vol. 25, No, 7 : Water and Plant Anatomy. By Prof. George J. Peirce. Pp. 215-220. Deposits of California. By Prof, Herbert I. Mason. Pp. 221-234t plates 23-44. (San Francisco, Calif.: California Academy of plates 23-44. (San Francisco, Calif.
Sciences.) Jamaica. Annual Report of the Department of Agriculture for the Year ended 31st March 1943. Pp. 20. (Kingston: Government Printer.)
Smithsonian Institution: United States National Museum. Contributions from the United States National Herbarium, Vol. 29, Part 1: Taxonomic Studies of Tropical American Plants. By C. V. Morton. Pp. $x i+86$. (Washington, D.C.: Government Printing Office.) 25
[317

U.S. Department of Agriculture. Circular No, 675: Control of the Mexican Bean Beetle in Irrigated Districts in the West. By R. L. Wallis. Pp. 12. (Washington, D.C.: Government Printing 